\title{
"The business effects of mega-sporting events on host cities: an empirical view"
}

\begin{tabular}{|c|c|}
\hline AUTHORS & $\begin{array}{l}\text { Christian Tabi Amponsah (D https://orcid.org/0000-0002-5523-2744 } \\
\text { Gouher Ahmed (D https://orcid.org/0000-0001-7686-7581 } \\
\text { Manoj Kumar (D https://orcid.org/0000-0002-6452-6445 } \\
\text { Samuel Adams (D https://orcid.org/0000-0003-1543-8729 }\end{array}$ \\
\hline ARTICLE INFO & $\begin{array}{l}\text { Christian Tabi Amponsah, Gouher Ahmed, Manoj Kumar and Samuel Adams } \\
\text { (2018). The business effects of mega-sporting events on host cities: an empirical } \\
\text { view. Problems and Perspectives in Management, 16(3), 324-336. } \\
\text { doi:10.21511/ppm.16(3).2018.26 }\end{array}$ \\
\hline DOI & http://dx.doi.org/10.21511/ppm.16(3).2018.26 \\
\hline RELEASED ON & Tuesday, 28 August 2018 \\
\hline RECEIVED ON & Wednesday, 14 February 2018 \\
\hline ACCEPTED ON & Wednesday, 18 July 2018 \\
\hline LICENSE & $\begin{array}{l}(c c) \text { EY-NC } \\
\text { This work is licensed under a Creative Commons Attribution-NonCommercial } 4.0 \\
\text { International License }\end{array}$ \\
\hline JOURNAL & "Problems and Perspectives in Management" \\
\hline ISSN PRINT & $1727-7051$ \\
\hline ISSN ONLINE & $1810-5467$ \\
\hline PUBLISHER & LLC "Consulting Publishing Company "Business Perspectives" \\
\hline FOUNDER & LLC "Consulting Publishing Company "Business Perspectives" \\
\hline
\end{tabular}

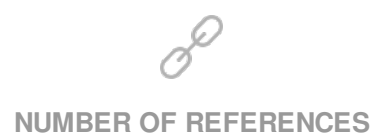

48
NUMBER OF FIGURES

5
NUMBER OF TABLES

4

(C) The author(s) 2022. This publication is an open access article. 


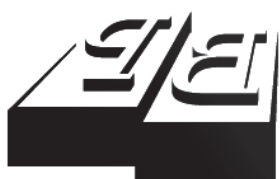

BUSINESS PERSPECTIVES

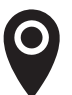

LLC "CPC "Business Perspectives" Hryhorii Skovoroda lane, 10, Sumy, 40022, Ukraine

www.businessperspectives.org

Received on: $14^{\text {th }}$ of February, 2018 Accepted on: $18^{\text {th }}$ of July, 2018

c Christian Tabi Amponsah, Gouher Ahmed, Manoj Kumar, Samuel Adams, 2018

Christian Tabi Amponsah, Ph.D., Assistant Professor of Management, Yorkville University, Vancouver Campus, British Columbia, Canada.

Gouher Ahmed, Ph.D., PMP Professor of International Management, Skyline University College, Sharjah, UAE.

Manoj Kumar, Ph.D., Associate Professor of Marketing, Skyline University College, Sharjah, UAE.

Samuel Adams, Ph.D., Professor, Ghana Institute of Management and Public Administration, Dean of the School of Public Service and Governance, Ghana.

\section{(ㄷ)(1) $(8$}

This is an Open Access article, distributed under the terms of the Creative Commons Attribution-NonCommercial 4.0 International license, which permits re-use, distribution, and reproduction, provided the materials aren't used for commercial purposes and the original work is properly cited.

Christian Tabi Amponsah (Canada), Gouher Ahmed (USA),

Manoj Kumar (United Arab Emirates), Samuel Adams (Ghana)

THE BUSINESS EFFECTS

OF MEGA-SPORTING EVENTS ON HOST CITIES: AN EMPIRICAL VIEW

\begin{abstract}
The study is an empirical view of the important issue of the business effects of the mega-sporting events (MSEs), like the Olympic Games, on which there are favorable and unfavorable views, the design of the study is to go through different views and find out the effects from knowing or knowledgeable persons of the event with the help of a sample of 155 respondents drawn randomly from across the continents in the form of opinions on the positive and negative effects of the MSEs through a questionnaire, containing questions on economic development, infrastructure development, environment, lifestyles, etc., and their favorable and unfavorable responses were elicited. The data collected have been analyzed in terms of the characteristics of respondents and their negative and positive responses on the Olympic and FIFA. The findings on the whole of study show that the hosting of the MSEs has positive effects on the economy and society of the host cities through the influx of tourists, infrastructure development, and image promotion of the country, among others, notwithstanding the certain drawbacks in terms of environmental disturbances, and some inconveniences to the locals.
\end{abstract}

Keywords

JEL Classification mega-sporting events, host cities, economy, society, environment

L83

\section{INTRODUCTION}

In the last four decades or so, there have been a number of studies on effects of business on major mega-sporting events (MSEs), which are international in scope and include those organized by the International Olympic Committee (IOC) - Olympic Games, Federation Internationale de Football Association (FIFA) - World Soccer Cup and National Football League (NFL) - Super Bowl, etc. As per Roche (2000), for example, MSEs also have cultural, business, tourist and other dimensions that impact upon the host city or nation. For instance, Olympic Games is the greatest sports event in the world, with thousands of participants from all nations, involves great billions of expenditures, great infrastructure, etc. The Olympic Games naturally have attracted a good deal of impact Assessment-Attention at the academic hands.

So is the case with other MSEs like the FIFA Soccer World Cup and others as Asia and Commonwealth Games, which leave a lasting impact upon the sponsor city or country, with a good amount of competition among the cities and nations to sponsor and play host to MSEs (Collins, 2006; FIFA, 2012).

The effects of MSE are expected to be generally beneficial even otherwise, they are worth evaluating to neutralize the ill-effects, which expected to flow too from such mega-events, which are very challenging 
to the hosts in terms of organization, finances and facilities and hospitality. What is the management model of the MSEs? It is an interesting question, but not attempted in this study of effects (Es).

It is not for the reason that the MSEs are hotly contested for holding and held with great toil and expenditure and organizational structure, the motives being varied, cultural, economic and environmental benefits (Amponsah \& Ahmed, 2017; Collins et al., 2006), health and human rights (Houston, 2000), stockmarket price rise (Zawadzki, 2013), national and international exposure (Matheson, 2006), promotion of national culture globally (Ahmed, 2018; Dolles \& Soderderman, 2008), economic growth, infrastructure build-up and image promotion; say also the holy trinity of MSEs effects (Matos, 2006). Urban and regional promotion (Maharaj, 2009; Walker et al., 2010), during and after the mega-sporting events (Boumann \& Matheson, 2013). Above all, there may be the motive of demonstrating the economic strength, sporting power and organizational skill.

There are a few studies that emphasize the negative effects of mega-events in a wide range of areas on the host cities, such as of Jones (2001). There are others who question the benefits of events on host cities (Chalip, Green, \& Hill, 2003; Ritchie \& Smith, 1991; Smith, 2005). Barclay (2009), for example, claims that the economic benefits of hosting MSE are often exaggerated as costs are underestimated. The hosts are said to "systematically and self-servingly mislead" (Horne \& Manzenreiter, 2006, p. 10), which puts the effects of MSEs in the realm of uncertainty. They may be sponsored just for national honor, as hosting a MSE puts the host city/nation in international limelight as a sports lover, which does not much mind the expenditure of hosting the event, which is quite considerable.

There is stiff competition between potential hosts, with perhaps more money spent on bidding than on arrangements and facilities. There is a lot of lobbying and international power play. The hosts assure themselves of many benefits of developments, tourism, hospitality, business demand, employment and international exposure.

So, the question to be addressed is what are the effects (Es) of MSEs in the host country?

The IOC, in an amendment to its charter, makes it clear that the games are intended to help in the promotion of sustainable development, environmental well-being and cultural interaction, all beneficial intentions (International Olympic Committee, 2003, 2004, 2010, 2012). What, however, is the reality? This study addresses this question.

Accordingly, the present study is an investigation of the problem of the effects of mega-sporting events in terms of their business effects, their effects of spreading the culture of sports and healthy competition being quite well taken for granted. So also name and fame and prestige MSEs hosting city/state/countries get across the globe.

The events are manifestations of national pride, nation's culture, economic and business strengths, organizational capabilities and international standing. However, the business problem is how business effects are to be sought and in what terms. Then there is the research problem from whom. The business effects are mainly sought in terms of infrastructure and economic development, environmental and social impact. For this purpose, a sample of respondents was drawn from across the globe and their views elicited through a questionnaire. It is a novelty of the study to ascertain the views of a knowledgeable and otherwise, on the mega-sporting events of Olympic and FIFA Games, which set the example for the business effects of the MSEs and dispel wrong notions of their ill-effects.

If indeed, the very foundation and the overarching goal of the mega events in the long run is to improve the citizens' welfare, then it is important to explore the perception of stakeholders of the intended costs and benefits. This research is consistent with the theoretical foundation that policy is a function of pub- 
lic opinion. Soroka and Wlezien (2010) claim that a principal function of representative democracy is to provide a mechanism through which public opinion and public policy are integrated. Parsons and Smelser (2005, p. 10) put it simply by stating that 'Public opinion is to political market what consumes demand is to economic marketplace'.

Finally, hosting a major event might raise the perception of the city so that it becomes a "major league" or "world class" city and a travel destination. All of these claims are potentially true, although little empirical research has conclusively demonstrated any long-run connections between hosting mega-events and future tourism demand. The findings and recommendations help the other countries facing similar challenges. In addition, it would provide the local sporting leaders some (arm's length) guide in what they perceive as the securing of such an event as an opportunity to improve economic and social aspects of a city or region through the accumulated investment triggered by staging the Games.

The structure of the study is as follows: introducing the subject of the study, review of literature, hypotheses formulation, presentation and analysis of data, summary, conclusion and recommendation.

\section{LITERATURE REVIEW AND HYPOTHESES}

First, the bids for MSEs are said to be based on their assumed benefits. Houston (2000) and Kim et al. (2013) have been of this perception, and the benefits have been seen in many ways, such as economic and infrastructural development.

Horrocks and Stewart (1999) claim that mega-sporting events could promote health rights. Referring to South Africa's bid for the 2004 Olympic Games, Pillay and Bass (2008) argue that it was a 'Developmental Bid' intended to promote growth and bring down inequalities and poverty, so Olympic Games can be an instrument of development of an under-developed and developing country.

Dolles and Soderman (2008) claim that MSEs today are central stages that not only feature professional athletes representing their countries in competing for excellence, but also provide host nations with a universally legitimate way to present and promote their national identities and cultures on a global scale. Chappelet (2012) observes that mega-sporting events have both tangible and intangible benefits, short- and long-term, intentional and unintentional, local and global benefits that he describes as legacies associated with MSEs even if they lose the bid. However, he notes that legacy essentially is a dream to be pursued rather than a certainty to be achieved. The benefits associated with not winning a bid is what Chappelet refers to as "losing is winning" even when one does not win a bid. He notes that despite failing to obtain the 2006 Winter Games, the city of Sion, in Switzerland, constituted a foundation to perpetuate the main theme of its candidature: sustainable development for the mountain regions. After nearly a decade after the decision in favor of Turin, the foundation is still very active and may be considered as a legacy of the Sion's failed bid. According to Alberts (2009), the Olympics provides a positive legacy for failed bid cities, giving them "an opportunity to carry out or speed up urban development projects that might otherwise not be realized or only much later".

Rose and Spiegel $(2010,2011)$ claim that the Olympics has what they describe as the trade effect, which suggests that countries that bid for the Olympics are sending a signal that they are ready to open up trade. Looking at the MSE comprehensively, Tavakkoli (2016) asserts that mega-events have not only economic benefits, but also historical, cultural, and political ramifications. In support of this view, Matheson and Baade (2004) aver that the struggle to host and manage MSEs has been an essential portion of urban politics of prestige and opportunity.

Using a standard gravity model of bilateral tourism flows between 200 countries over the period 1995-2006, Fourie and Santana-Gallegouu (2011) examine the impact of six mega-sporting events find a statistically significant effect on tourism, an 8 per cent increase in tourism in the years of the 
event. But, while four of the six mega-events have an economically and statistically positive impact on tourist arrivals, the Rugby World Cup and the Winter Olympic Games have a negative impact on tourism, ceteris paribus. Rose and Spiegel (2010) also find no evidence of an increase in trade with hosting the Winter Olympic Games. They, however, using a variety of trade models based on signaling theory, find that hosting a mega-event like the Olympics has a positive and statistically significant impact on national exports. The effect of trade is $30 \%$ higher for countries that have hosted the Olympics, and more importantly, unsuccessful bidders also seem to enjoy the benefits of expanded exports.

The Olympics are the mega-sporting events in which whether you win or lose in your bid, you are still a winner, this supports the 'win if even you lose' principle, the seeming principle particularly of the Olympic bids. The very fact of a nation bidding for the Olympic means that it is good as any other bidder and shines in the limelight of Olympic bidding and derives its windfall gains.

\subsection{Non-benefit}

There is, however, a non-benefit school of scholars of the effects of the MSEs. Horrocks and Stewart (1999) argue that MSEs have the potential to threaten life and thereby diminish spectators and athletes' expectations of recreation, health and well-being with reference to the Beijing Olympics. Gaffney (2010) claims that the physical transformation associated with MSE is linked with the clearing of low-income neighborhoods and displacement of thousands of people through the physical destruction or market mechanism through rent inflation.

Using the social exchange theory, Deccio and Baloglu (2002) showed that the increase in the price of goods and property rates affect not only host cities, but also has spillover effects on nonhost communities. Tavakkoli (2016) also identifies negative social impacts associated with the 1996 Atlanta Olympic Games. He notes that over the period 1990-1995, 9,500 units of affordable housing were lost and USD 350 million of public funds were diverted from low-income housing, social services, and other support services for homeless and poor people to Olympic preparation. Many other studies suggest that many of the pro-MSE advocates ignore the environmental impacts and even when they do, usually do not follow up on environmental remediation strategies expected to be put in place to deal with the large amount of carbon emissions associated with MSEs (Lenskyj, 2008; Gaffney, 2010; Ahmed \& Pretorius, 2010). This is especially important in light of the fact that the carbon footprint for the 2010 World Cup in South Africa, for example, was estimated at 2.75 million tons of carbon dioxide, which is nearly ten times the value of World Cup in Germany in 2006 and more than twice as high as of the Beijing Olympics.

Barclay (2009), on the other hand, claims that the economic benefits of hosting mega-sporting events are often exaggerated. He argues that ex-ante impact studies typically overestimate the gains and underestimate the costs involved. Also, Matheson and Baade (2004) offer three theoretical foundations as to why MSE may not yield the expected befits, including displacement costs, crowding out, and multiplier effects. Spending on a mega-event displaces spending that would have occurred otherwise as local residents purchase tickets to the event rather than spend that money on other activities in the local economy. This substitution effect simply results in a reallocation of expenditures in the economy rather than a real net increase in economic activity (Matheson, 2002). Second, Matheson and Baade (2004) argue that event attendees may simply supplant other tourists who would normally visit the host venues. They note that an event that attracts over a million tourists but displaces an equal or slightly lower number of tourists may have an overall negligible impact. This is especially so for communities that are already popular tourist destinations, where incoming MSE attendees would just supplant rather than supplement the regular tourist economy to boost overall local development (Matheson, 2006).

Finally, in estimating the total economic benefits of MSE, many overlook leakages associated with the MSE so that the multiplier benefits ignore multiplier costs and hence the benefits are grossly overstated. Lee (2001) identifies non-economic costs such as traffic congestion, vandalism, environmental degradation, disruption of residents' lifestyle associated 


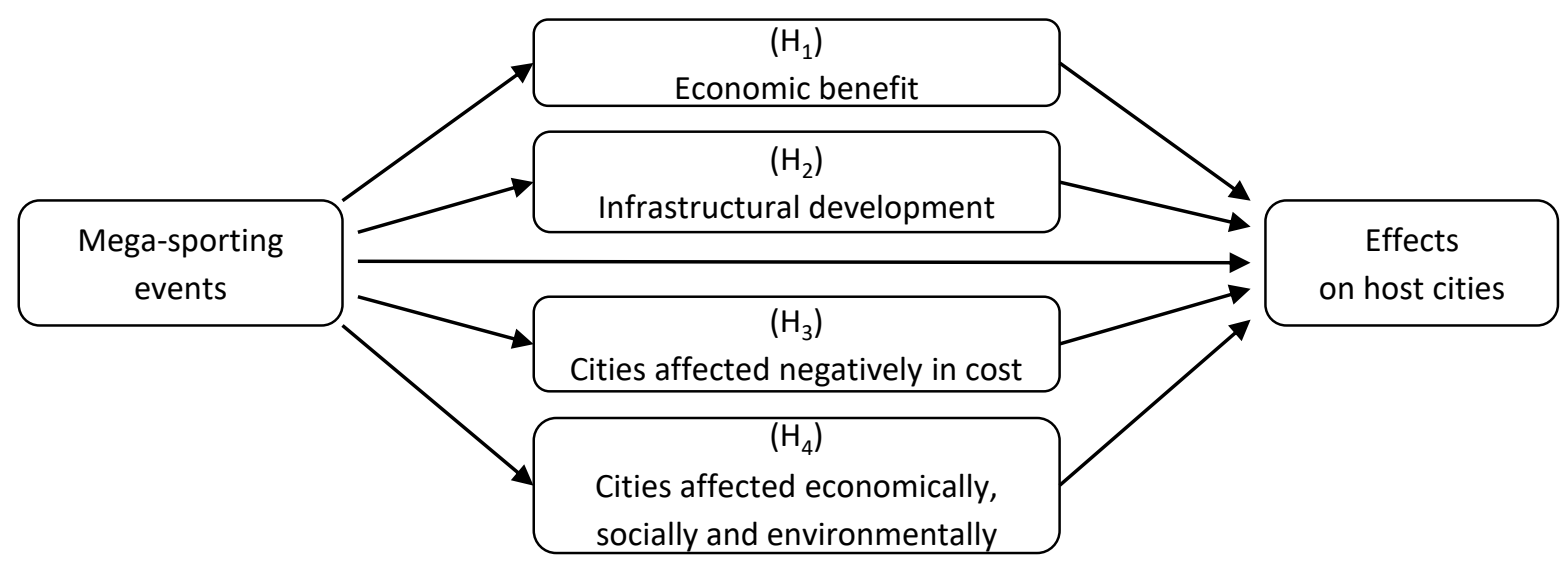

Figure 1. Mega-sporting event model

with MSE which are often not reported. These views are consistent with Conway, Isselhard, \& Urbanski's (2007) argument that the true benefits of an MSE can only be known after all the direct, indirect and induced effects or expenditures are accounted for. In a related study, Coates and Humphreys (2003) find that cities that win the MSE (Super Bowl) tend to experience a tremendous increase in their per capita incomes following the game and not the host cities. Similarly, Matheson and Baade (2004) and Baade and Matheson (2004) show that both the Montreal Olympics and USA 1994 World Cup did not achieve the expected financial goals. For example, a net loss of over USD 5 billion was experienced as opposed to the nearly planned USD 4 billion gain. Porter and Fletcher (2008), on the other hand, find that the 1996 Summer Olympics and the 2002 Winter Olympics did not lead to any substantial changes in the host cities.

From the discussion above, the benefits of an MSE cannot be determined apriori. As noted by Fourie and Satana-Gallago (2011), the net effect of MSE in promoting tourism, for example, is dependent on the type of mega-event, the participating countries, the host country's level of development, and whether the event is held during the peak- or off-season. In other words, it is always an empirical matter.

In the light of the conflicting views of the effects of the MSEs, we formulate the following hypotheses (Hs) and see how they stand with the empirical data.

H1: Mega-sporting events positively affect the economic development of host cities.
H2: Mega-sporting events speed up infrastructure development of host cities.

H3: Hosting mega-sporting events have negative effects on host cities in terms of cost.

H4: Hosting mega-sport events have negative effects on host cities economically, socially, and environmentally.

The methodology used is described next.

\section{OBJECTIVES AND METHODOLOGY}

The study objectives are:

1) to take note of different views on the business effects of the mega-sporting events;

2) to investigate the effects empirically through a sample of knowledgeable global community;

3) to have balance sheet views of effects of the MSEs;

4) to draw meaningful conclusions and policy implications.

The objectives are to explore the effects of mega-sporting events (based on citizens' perception) on host cities in an effort to inform the increasing number of cities keenly interested in bidding to host the mega-games and safeguard the increasing funds invested in the games. It is expected there- 
fore that the findings of the study and more importantly the recommendations could provide the local sporting leaders and governments some information about identifying the true costs and benefits of bidding and executing mega-sporting events.

\subsection{Study methodology}

To achieve the objectives of the study, data were collected from 155 participants pertaining to the Olympics and FIFA drawn from local committees that host the games and government authorities that have been involved in the hosting of the games. The questionnaire method was used for data collection questions (Qs) were framed pertaining to different items and responses elicited in the form of 5-point Likert scale responses of (1) strongly disagree to (5) strongly agree, to judge the degree of responses of the sample respondents to the benefits and non-benefits or disadvantages of the MSEs of the Olympic Games and FIFA of general and special category, respectively, and of varying mega scale.

\subsection{Data collection}

The questionnaire was designed using the guidelines outlined by Dillman (1991). However, some changes and modifications were made to the scale items to make them appropriate for the study.
Respondents selection and data collection were done digitally over a period of about 17 weeks. The data pertaining the period to 2013-2014 may be seen as not applicable to present day conditions of, say, MSEs becoming more mega with heavy costs and far reaching results. However, it is unlikely to help any change in the nature of positive events and their overall economic and business effects. It's the NET EFFECT that always counts.

Finally, out of the 206 respondents contacted, 155 responded with full data particulars being an enlightened group of respondents, the sample 155 can be well taken as a representative sample of the general public, the views, of which count regarding the outcomes of the MSEs, the sample of which were just two in the study, namely Olympics and FIFA World Cup, which can be ranked as No. 1, No. 2 MSEs which, in fact they are, their ES representing the 'Es' in general of the MSEs. The sample is international in tune with the international nature of the sample MSEs.

\section{ANALYSIS}

The demographic information of the study participants is shown in Table 1 . Out of the 155 participants, males were 134 , females were 21. Approximately $92 \%$ of respondents were

Table 1. Demographic profile of respondents

\begin{tabular}{|c|c|c|}
\hline Characteristics & Valid N & Percentage \\
\hline \multicolumn{3}{|l|}{ Gender (valid N = 155) } \\
\hline Male & 134 & 86 \\
\hline Female & 21 & 14 \\
\hline \multicolumn{3}{|l|}{ Age (valid $N=155$ ) } \\
\hline $18-25$ & 2 & 1 \\
\hline $26-35$ & 18 & 12 \\
\hline $36-45$ & 33 & 21 \\
\hline $46-55$ & 89 & 57 \\
\hline 56 and over & 13 & 8 \\
\hline \multicolumn{3}{|c|}{ Educational level (valid $N=155$ ) } \\
\hline Bachelor degree & 117 & 75 \\
\hline Master degree & 32 & 21 \\
\hline Doctorate degree & 3 & 2 \\
\hline Other & 3 & 2 \\
\hline \multicolumn{3}{|l|}{ Affiliation (valid N = 155) } \\
\hline FIFA & 56 & 36 \\
\hline $\mathrm{IOC}$ & 65 & 42 \\
\hline Other & 34 & 22 \\
\hline \multicolumn{3}{|l|}{ Nationality (valid $N=155$ ) } \\
\hline Africa & 21 & 14 \\
\hline Americas & 23 & 15 \\
\hline Asia & 43 & 28 \\
\hline Europe & 61 & 39 \\
\hline Oceania & 7 & 5 \\
\hline
\end{tabular}


between the age of 18 and 55, with the major age group between 26-35 (57\%). Among the respondents, $98 \%$ had completed university or received higher levels of education; $21 \%$ of respondents had Master degrees. The responses came from various countries around the world; therefore, the nationalities of the participants were incorporated according to geographical regions and composition. More than $50 \%$ of responses came from Europe, possibly due to the recent Olympic Games in London and the fact that Europe has hosted most of the FIFA and Olympic Games than any other continent.

Expectantly, IOC stands first in respondent affiliation with 65 and $42 \%$ followed closely by FIFA 56 and 36\%, also quite impressive. Nation-wise, European nations with 61 and $39 \%$, followed by Asia 43 and 28\%, other 34 and $22 \%$, Americas 23 and $15 \%$ and Africa 21 and $14 \%$ again not expectantly, Europe being MSEintensive, both in Olympics and FIFA, and Asia as the largest of the continents. The USA is just ahead of Africa, a rising sports continent and also a fast developing one.

The results of the survey show the difference between how the respondents rated the effects and efforts of FIFA World Cup and the Olympic Games on host cities. The mean and standard deviations of the factors on a 5-point Likert scale were sorted in a descending order of magnitude, as shown in Table 2.

The economic development of a host city for both the Olympic Games and the World Cup received a mean value of more than 2.6, which suggest that respondents think that the Olympic Games and the World Cup significantly accelerate economic development of the host city. The other two items were also rated relatively high, with the lowest response to "staging the World Cup disrupts lifestyles and routines of host residents". The standard deviations of the factors ranged from 0.55 to 0.82 , which illustrated the consistent level of rating by the participants (Table 2).

The Olympic sports event is the greatest of the sports event on the earth, with thousands of participants from across the globe with a village built for its purpose, and with expenditure running into billions of USD. It's an episode in the economic development of the sponsoring country. It creates an atmosphere of festivity, so whatever substance in the daily routine of the most citizens in a welcome disturbance, and a life time opportunity. As significant as the Olympics seem to be FIFA World Cup event are their mean (2.68 and 2.67) and standard deviation values ( 0.5 and 0.56$)$. Thus, in the extent of economic benefit, the Olympics games are just a step ahead of FIFA world cup is a single game in life style disturbance too, the mean values of the two are 2.3 and 2.22 , respectively. On the whole, the Table 2, data bring good tiding regarding the two super sports events of the Olympics and FIFA world cup.

Table 2. Mean and standard deviations of a 5-point scale items

\begin{tabular}{|c|c|c|c|}
\hline Rank & Factor & Mean & $\begin{array}{c}\text { Std. } \\
\text { deviation }\end{array}$ \\
\hline 1 & $\begin{array}{l}\text { The extent to which } \\
\text { the Olympic Games } \\
\text { accelerate economic } \\
\text { development of host } \\
\text { cities }\end{array}$ & 2.68 & 0.58 \\
\hline 2 & $\begin{array}{l}\text { The extent to which the } \\
\text { World Cup accelerates } \\
\text { economic development } \\
\text { of host cities }\end{array}$ & 2.67 & 0.55 \\
\hline 3 & $\begin{array}{l}\text { The extent to which the } \\
\text { staging the Olympic } \\
\text { Games disrupts } \\
\text { lifestyles and routine life } \\
\text { of host residents }\end{array}$ & 2.3 & 0.82 \\
\hline 4 & $\begin{array}{l}\text { The extent to which } \\
\text { staging of the World } \\
\text { Cup disrupts lifestyles } \\
\text { and routines of host } \\
\text { residents }\end{array}$ & 2.22 & 0.77 \\
\hline
\end{tabular}

For the next six factors, out of 14 , the 5-point Likert were sorted out in a descending order of magnitudes on the basis of the mean values and presented in Table 3. From the results, the factor "the Olympic Games speed up infrastructure development" received the highest mean value of more than 4.24 suggesting that the respondents did agree or strongly agree with the fact that the Olympic Games accelerate urban infrastructure development. Thus, improve the quality of life of the sponsoring city. The next two factors "the IOC would encourage societal support of its events by acting in a socially responsible way" and "the World Cup speeds up infrastructure development" generally had high mean values, significantly, of 4.06 each. They mean that more than $80 \%$ of the 
participants agree or strongly agree with these favorable or beneficial business effects factors. The factor "FIFA would encourage societal support of its events by acting in a socially responsible way" received a lower mean value of 3.74 , in comparison with the IOC's is 4.06 , which puts the Olympic in a more responsible social position.

The last two items measuring alternatives of spending financial resources on the mega-sporting events had relatively low mean values of 2.93 (Olympics) and 2.87 (FIFA). This shows that less than $30 \%$ of respondents think that the money spent on staging mega-sporting events could be better used to improve the quality of life of people. The standard deviations of the items, ranging from 0.80 to 1.06 , show the relatively consistent level of responses. But, the deviations or standard deviations values of No. 5 and 6 items are $>1.00$. Once again, or in terms of 6 items of Table 3, the swing is favor of the MSEs, as represented by the mega of the mega-sporting events of the Olympic Games and the FIFA World Cup. To these must be added the favorable responses of Table 2, making a total of 10 factors. If the last two factors of alternative spending are taken out, the 'Yes' or 'Acceptance' or beneficial business effects scope is $8 / 10$. Table 2, 3 and 4 items are about the disturbance to the citizens, 'life style' or routine life also taken out, the combined score of Tables 2 and 3 is $6 / 10=60 \%$ which is quite democratic and winning score, of a well-informed sample global population.

In the light of Tables 2 and 3 stats, the keen bids to hosts of the 3 MSEs in general and the Olympic and FIFA contests, in particular favorable business effects justification too, with the benefits (Bs) of the (megas) over running their costs $(\mathrm{C}) . \mathrm{B} / \mathrm{C}>1$.

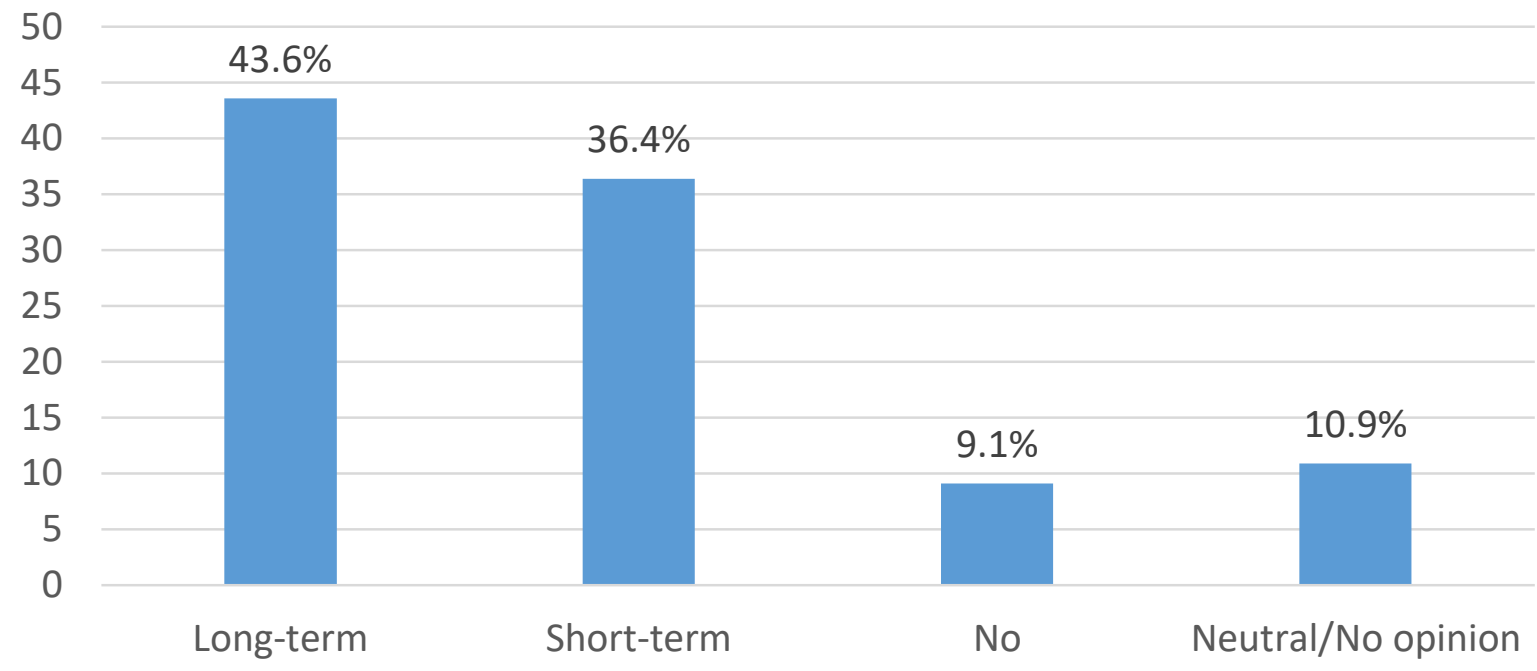

Figure 2. Benefits that FIFA sporting events bring to the society

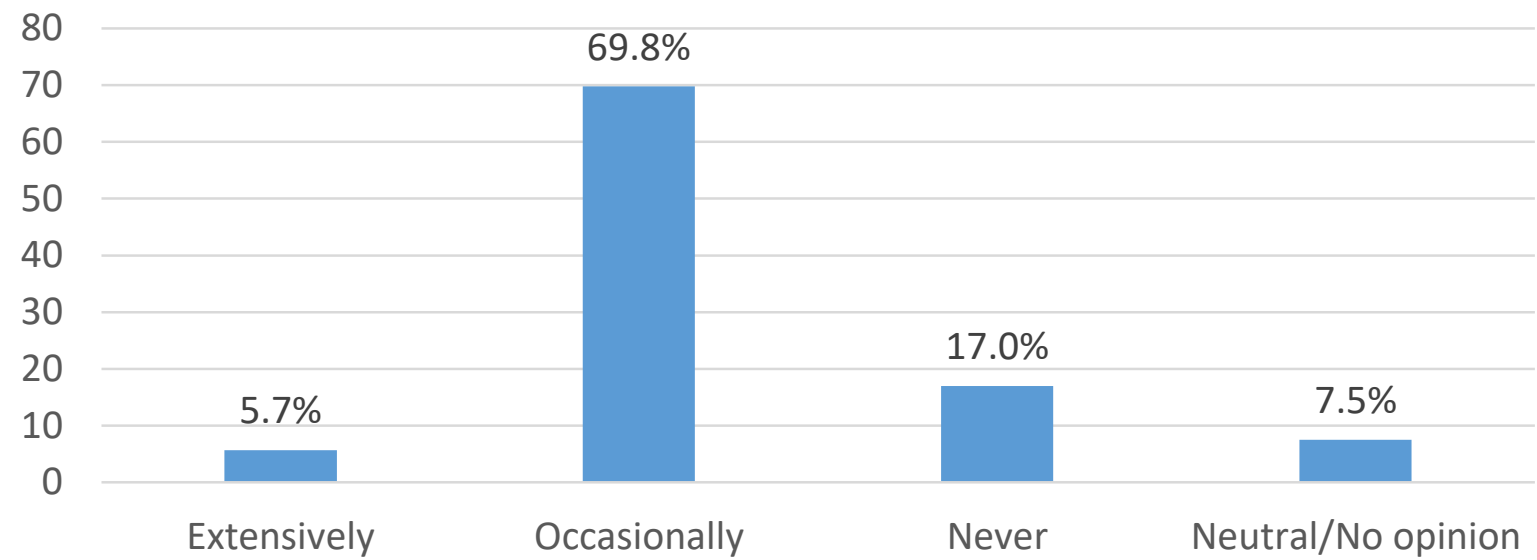

Figure 3. Benefits that the Olympic Games sporting events bring to the society 
Table 3. Mean and standard deviations of a 5-point scale items

\begin{tabular}{|c|c|c|c|}
\hline Rank & Factor & Mean & $\begin{array}{c}\text { Std. } \\
\text { deviation }\end{array}$ \\
\hline 1 & $\begin{array}{l}\text { The Olympic Games speed } \\
\text { up urban infrastructure } \\
\text { development }\end{array}$ & 4.24 & 0.80 \\
\hline 2 & $\begin{array}{l}\text { The IOC would encourage } \\
\text { societal support of its } \\
\text { events by acting in socially } \\
\text { responsible way }\end{array}$ & 4.06 & 0.83 \\
\hline 3 & $\begin{array}{l}\text { The World Cup speeds } \\
\text { up urban infrastructure } \\
\text { development }\end{array}$ & 4.06 & 0.81 \\
\hline 4 & $\begin{array}{l}\text { FIFA would encourage societal } \\
\text { support of its events by acting } \\
\text { in socially responsible way }\end{array}$ & 3.74 & 0.89 \\
\hline 5 & $\begin{array}{l}\text { Money spent on staging the } \\
\text { Olympic Games should be } \\
\text { better spent to improve the } \\
\text { quality of life of citizens }\end{array}$ & 2.93 & 1.04 \\
\hline 6 & $\begin{array}{l}\text { Money spent on staging the } \\
\text { Olympic Games should be } \\
\text { better spent to improve the } \\
\text { quality of life of citizens }\end{array}$ & 2.87 & 1.06 \\
\hline
\end{tabular}

The benefits that the IOC and FIFA bring to the society were divided into four categories in the questionnaire. The opinions of the respondents are il- lustrated in Figures 2 and 3. More than $90 \%$ of the participants believe that the Olympic Games bring short-term and long-term benefits to the society, while $80 \%$ of the respondents think that the World Cup brings the same benefits to the society. On the other hand, $4 \%$ answered that there are no benefits to society from staging the Olympic Games, and 9\% did not find any benefits that the society received from hosting the FIFA World Cup.

When the participants were asked about the negative effects of the Olympic Games and the World Cup on the environment, almost $70 \%$ and about $60 \%$, respectively, mentioned occasional negative effects. Only $5.7 \%$ and $7.4 \%$ of the participants agreed with extensive negative effects of the Olympic Games and FIFA World Cup, respectively. However, $17 \%$ replied that the Olympic Games have no negative effects on the environment, and around $20 \%$ of the respondents also noticed no negative environmental effects from staging the FIFA World Cup as depicted in Figures 4 and 5 below.
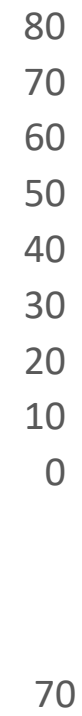

60

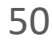

40

30

20

10

0

\section{$69.8 \%$}

$17.0 \%$

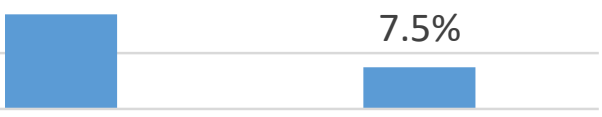

Never

Neutral/No opinion

Occasionally

Extensively

Figure 4. Staging the Olympic games has negative impacts on the environment

$$
\begin{aligned}
& 0 \\
& 50 \\
& 0 \\
& 0 \\
& 0 \\
& 0 \\
& 0
\end{aligned}
$$

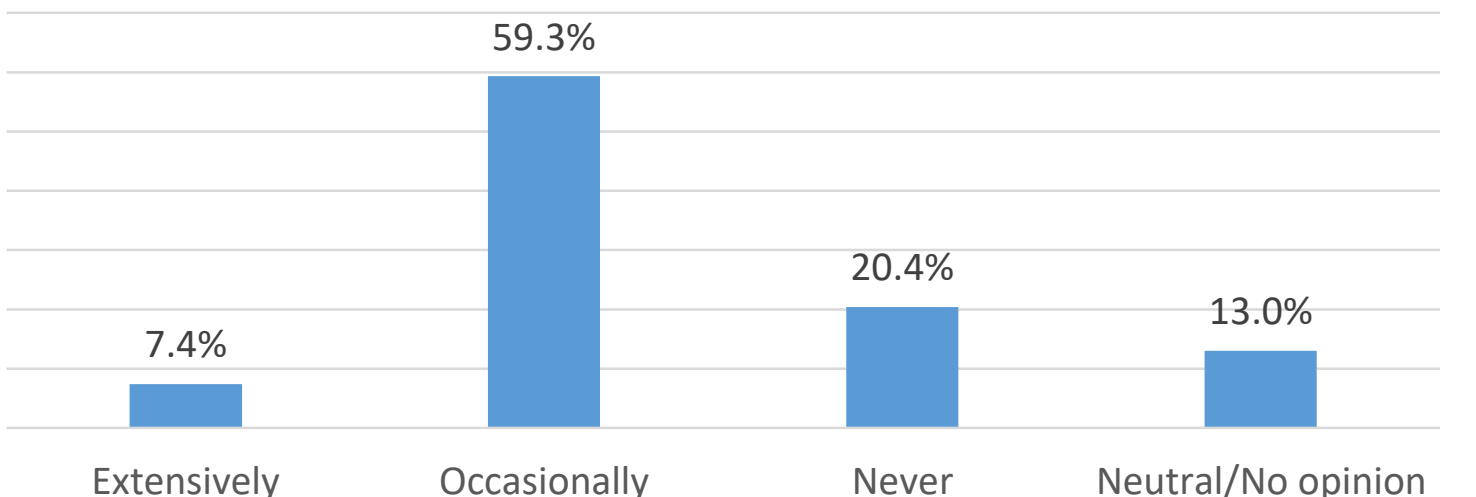

Extensively Occasionally Never Neutral/No opinion

Figure 5. Staging the World Cup has negative impacts on the environment 
Table 4. Results of hypotheses testing

\begin{tabular}{|c|c|c|c|c|}
\hline \multicolumn{2}{|r|}{ Hypotheses } & The IOC credible interval & FIFA credible interval & Result \\
\hline $\mathrm{H} 1$ & $\begin{array}{l}\text { Mega-sporting events positively affect } \\
\text { economic development of host cities }\end{array}$ & $73 \pm 11 \%$ & $70 \pm 11 \%$ & Supported \\
\hline $\mathrm{H} 2$ & $\begin{array}{l}\text { Mega-sporting events speed up infrastructure } \\
\text { development of host cities }\end{array}$ & $87 \pm 7.7 \%$ & $80 \pm 9.4 \%$ & Supported \\
\hline $\mathrm{H} 3$ & $\begin{array}{l}\text { Hosting mega-sporting events have negative } \\
\text { effects on host cities in terms of cost }\end{array}$ & $90 \pm 6.5 \%$ & $78 \pm 9.8 \%$ & Supported \\
\hline $\mathrm{H} 4$ & $\begin{array}{l}\text { Hosting mega-sport events have negative } \\
\text { effects on host cities economically, socially, } \\
\text { and environmentally }\end{array}$ & $78 \pm 9.8 \%$ & $61 \pm 12 \%$ & Partly supported \\
\hline
\end{tabular}

Note: $p=0.95$.

\subsection{Hypotheses testing}

An $R$-project statistical package was used to test the research hypotheses by calculating the posterior probability and credible interval for the population proportion using the hypergeometric distribution. The range of the credible interval is the criterion that was used to define whether a hypothesis is supported or not. If the credible interval was entirely above $50 \%$, then a hypothesis was supported.

Hypothesis 1 posits that mega-sporting events positively affect the economic development of host cities. Two factors measured the economic development of a host city from staging the Olympic Games and the World Cup supported Hypothesis 1 , as credible intervals of positive answers were equal to $73 \pm 11 \%$ with $p=0.95$ and $70 \pm 11 \%$ with $p=0.95$, respectively. For example, with the probability equal to $95 \%, 73 \pm 11 \%$ of 155 respondents agree that the Olympic Games significantly accelerate economic development of a host city.

Hypothesis 2 posits that mega-sporting events speed up infrastructure development of host cities. Hypothesis 2 received support from two factors that evaluated infrastructure development from staging the Olympic Games (credible inter$\mathrm{val}=87 \pm 7.7 \%, p=0.95$ ) and the World Cup (cred- ible interval $=80 \pm 9.4 \%, p=0.95)$.

Hypothesis 3 which indicates that hosting mega-sporting events have negative effects on host cities in terms of cost received support from two items. Out of 155 respondents, $90 \pm 6.5 \%$ with $p=0.95$ agree that the society does not benefit from staging the Olympic Games, while $78 \pm 9.8 \%$ agree that the society benefits from staging the World Cup.

Finally, Hypothesis 4 posits that hosting mega-sport events have negative effects on host cities economically, socially, and environmentally. For the IOC and FIFA, with $p=0.95$, credible intervals for the proportion of respondents agreeing with the Hypothesis 4 were equal to $78 \pm 9.8 \%$ and $61 \pm 12 \%$, respectively.

The hypotheses have evolved in the previous studies on the problem, as viewed in the literature review. That MSEs favorably impact upon economic and infrastructure and quicken them. Among others, Pillay and Bass (2008) study is very supportive of $H 1$ and $H 2$ (proved). As per $H 3$ and $H 4$, of negative cost, economic, social and environmental effects, there is a strong negative effects school of MSEs. Particularly, Matheson $(2002,2006)$ and Matheson and Baade $(2003,2004)$ studies are noted for this negative vision. Anytime, there is an opposing to any dominant school. In this study of 60 , there were negativist participants.

\section{CONCLUSION AND RECOMMENDATIONS}

The study has examined the economic, social, and environmental effects of MSE on host cities with a survey of 155 experts from around the world, its results show that MSE have positive effects on the economy and society of the host cities through the influx of tourists, infrastructure development, and raise awareness of a country, among others. On the other hand, the negative effects from staging the Olympic Games and the FIFA World Cup, are negative impacts on the environment and disturbance of lifestyles of host 
residents. However, the IOC and FIFA conduct numerous environmental and social programs focused on sustainable development of the society and on mitigation of the direct impacts of mega-sporting events on the environment, which in turn possibly compensate for the negative effects. Despite the negative effects of staging the mega-sporting events, the host cities derive more benefits rather than negative consequences.

Hence, it is recommended that any city, depending on its capacity may bid for and hold the MSEs, of which Olympics, FIFA World Cup come first and second, respectively. In 2017, for example, India, the Asian and world demographic major after China, for the first time eagerly held FIFA under 17 with great enthusiasm and had a good deal of sports infrastructural benefits at different cities, where the matches were played with the enthusiastic public response. Not a wish per was heard against the event, though the Indian team could not score much.

\section{FINDINGS AND LIMITATIONS}

The results indicate fundamental differences in the way the participants rated the impacts and efforts of the IOC and FIFA sporting events. About $45 \%$ of all participants did not mention any social and environmental programs conducted by the IOC and FIFA. Approximately $72 \%$ (based on answers to two questions about FIFA and the IOC) of the respondents think that the mega-sporting events accelerate economic development of a host city. More than $80 \%$ (based on answers to two questions about FIFA and the IOC) agree or strongly agree that mega-sporting events speed up urban infrastructure development, which brings some inconvenience to the host residents, about $47 \%$ (based on answers to two questions about FIFA and the IOC) of the participants agreed with the statement that the mega-sporting events disturb the lifestyles of host residents. More than $70 \%$ (based on answers to two questions about FIFA and the IOC) of the participants agreed and strongly agreed that enhanced urban infrastructure inherited after staging mega-sporting events and various social and environmental programs conducted by the IOC and FIFA encourage societal support.

About 65\% (based on answers to two questions about FIFA and the IOC) of the participants rated that mega-sporting events have occasional negative effects on the environment, and around 6.5\% (based on answers to two questions about FIFA and the IOC) think that the negative environmental effects are extensive.

As with many studies, this study is subject to some limitations worth noting, participants approached for the study were mainly from the IOCs and organizing committees of the Olympic Games and associations of FIFA around the world. Therefore, some participants might have been challenged to complete the questionnaire in the English language. Moreover, the respondents might have been nervous regarding who would see the completed questionnaire and how the results of the survey would affect them personally.

\section{CONTRIBUTION}

The study, in its own way but quite significantly, empirically clears the mist surrounding the effects of MSEs with reference to the two giant MSEs, Olympic Games and FIFA World Cup, with responses from across the globes that MSEs are not only beneficial by themselves, but also in economic and business terms by giving a boost to the host city economy and business.

\section{MANAGERIAL IMPLICATIONS AND FUTURE RESEARCH}

From the practical standpoint, this part that is focused on the effects of mega-sporting events on host cities helped to evaluate the level of awareness of the IOCs and FIFA associations with regard to negative and positive effects of the Olympic Games and the World Cup. The study found that $56 \%$ of the par- 
ticipants did not disclose their information about affiliation to the IOC or FIFA and those participants who did not disclose had a higher level of negative answers in comparison with the other group who mentioned their affiliation information. This fact can possibly mean that the participants with higher levels of negative answers did not mention their affiliation to one of the organizations, because they were afraid of who would see the completed questionnaire and that the results may affect them personally.

The findings suggest there is an enhanced urban infrastructure inherited after staging mega-sporting events, and various social and environmental programs conducted by the IOC and FIFA encourage societal support.

Future research on the subject should explore the relationship more fully in a longitudinal way. The sample size of the study was relatively small though reasonably large enough to permit the necessary power to test our hypothesis. Future works on the issues may use large samples to cover governmental institutions, government officials, non-governmental organizations and development partners to extend the generalizability of the studies.

\section{REFERENCES}

1. Ahmed, F., \& Pretorius, L. (2010) Mega-events and environmental impacts: The 2010 FIFA World Cup in South Africa. Alternation Journal, 17(2), 274-296

2. Ahmed, G. (2018). Transforming the UAE from Desert to Developed Economy. Forbes Middle East, $\operatorname{April}(70), 29$.

3. Alberts, H. C. (2009). Berlin's failed bid to host the 2000 Summer Olympic Games: Urban development and the improvement of sports facilities. Journal of Urban and Regional Research, 33(2), 502516.

4. Amponsah, C., \& Ahmed, G. (2017). New Global Dimension of Business Excellence. International Journal of Business Excellence, 13(1), 60-78.

5. Baade, R. A., \& Matheson, V. A. (2004). The quest for the cup: assessing the economic impact of the world cup. Regional studies, 38(4), 343-354.

6. Barclay, J. (2009). Predicting the costs and benefits of mega-sporting events: Misjudgment of Olympic proportions? Economic Affairs, 29(2) 62-66. https://doi.org/10.1111/ j.1468-0270.2009.01896.x

7. Baumann, R., \& Matheson, V. (2013). Infrastructure Investments and Mega-Sports Events: Comparing the Experience of Developing and Industrialized Countries (Worcester,
Massachusetts: College of the holy Cross, Department of Economics Faculty Research Series (No. 13-05), Working paper).

8. Chalip, L., Green, B., \& Hill, B. (2003). Effects of sport event media on destination image and intention to visit. Journal of Sport Management, 17(3), 214-234.

9. Chappelet, J. L. (2012). Mega sporting event legacies: a multifaceted concept. Papeles de Europa, suppl. Special issue: The economics of mega-sporting events, Madrid, 25, 76-86.

10. Coates, D., \& Humphreys, B. R. (2003). Professional sports facilities, franchises and urban economic development. Public Finance and Management, 3(3), 335-357.

11. Collins, A., Flynn, A., Wiedmann, A., \& Barrett, J. (2006). The environmental impacts of consumption at a sub-national level: The Ecological Footprint of Cardiff. Journal of Industrial Ecology, 10(3), 1-16.

12. Conway, J., Isselhard, C., \& Urbanski, E. (2013). The Economic Impact of Sport. The Review: A Journal of Undergraduate Student Research, 9(1), 18-23.

13. Deccio, C., \& Baloglu, S. (2002). Nonhost community resident reactions to the 2002 Winter Olympics: The spillover impacts. Journal of Travel Research, 41(1), 46-56.
14. Dillman, D. A. (1991). The design and administration of mail surveys. Annual review of sociology, 225-249.

15. Dolles, H., \& Söderman, S. (2008). Mega-sporting events in Asia impacts on society, business and management: An Introduction. Asian Business \& Management, 7(2), 147-162.

16. Federation Internationale de Football Association (2012). About FIFA's CSR. Retrieved from https://www.uefa. com/insideuefa/social-responsibility/ (Accessed on August 16)

17. Fourie, J., \& Santana-Gallego, M. (2011). The impact of mega-sport events on tourist arrivals. Tourism Management, 32(6), 1364-1370.

18. Gaffney, C. (2010). Mega-events and socio-spatial dynamics in Rio de Janeiro, 1919-2016. Journal of Latin American Geography, 9(1), 7-29.

19. Horne, J., \& Manzenreiter, W. (2006). An introduction to the sociology of sports mega-events. The Sociological Review, 54(2), 1-24.

20. Horrocks, M., \& Stewart, D. (1999). Sports events of extended duration particularly need thorough monitoring and planning. Enhancing Healthy Mega-Events: Planning for Health Rights. Paper presented at First International Conference on Sports and Human Rights 1-3, September 1999, Sydney, Australia. Retrieved from http://www.hrca.org. au/wp-content/uploads/2008/05/ 
how-you-play-the-game-fin.pdf (Accessed on August 16, 2018).

21. Houston, D. J. (2000). Publicservice motivation: A multivariate test. Journal of public administration research and theory, 10(4) 713-728.

22. International Olympic Committee (2010). The contribution of the International Olympic Committee to the millennium development goals. Retrieved from http://www. nosmoke55.jp/action/olympic_IOC-MDGs-report-eng.pdf (Accessed on 16 August, 2018)

23. International Olympic Committee (2012). The Olympic Movement. Retrieved from http://www.olympic. org/content/The-IOC/Governance/ Introductionold/ (accessed on April 17, 2012).

24. Jones, C. (2001). Mega-events and host-region impacts - determining the true worth of the 1999 Rugby World Cup. International Journal of Tourism Research, 3, 241-251.

25. Kim, D. Y., Fingler, J., Zawadzki, R. J., Park, S. S., Morse, L. S., Schwartz, D. M., Fraser, S. E., \& Werner, J. S. (2013). Optical imaging of the chorioretinal vasculature in the living human eye. Proceedings of the National Academy of Sciences, 110(35), 14354-14359.

26. Lee, S. (2001). A Review of Economic Impact Study on Sport Events. The Sport Journal, 4(2).

27. Lenskyj, H. J. (2008). Olympic industry resistance: Challenging Olympic power and propaganda. SUNY series on sport, culture and social relations. Albany: State University of New York Press.

28. Maharaj, B. (2009). Migrants and urban rights: Politics of xenophobia in South African cities. L'Espace Politique. Revue en ligne de géographie politique et de géopolitique, (8).

29. Matheson, V. (2006). MegaEvents: effect of the world's biggest sporting events on local, regional, and national economies (Faculty Research Series Paper No. 06-10). Worcester (MA): College of the Holy Cross, Department of Economics. Retrieved from https://crossworks. holycross.edu/cgi/viewcontent. cgi?article $=1067 \&$ context=econ_ working_papers (Accessed on August 16, 2018).
30. Matheson, V. A. (2002). Upon further review: an examination of sporting event economic impact studies. The Sport Journal, 5(1), 1-4.

31. Matheson, V. A., \& Baade, R. A. (2004). Mega-sporting events in developing nations: playing the way to prosperity? South African journal of economics, 72(5), 1085-1096.

32. Matheson, V., \& Baade, R. (2003). Mega-sporting events in developing nations: Playing the Way to prosperity? (Working Papers 0404. College of the Holy Cross. Department of Economics). https:// doi.org/10.1111/j.1813-6982.2004. tb00147.x

33. Matos, P. (2006). Hosting Mega Sports Events - A Brief Assessment of their Multidimensional Impacts. Paper presented at The Copenhagen Conference on the Economic and Social Impact of Hosting Mega Sport Events on 01/09/2006.

34. Olympic Movement (2003). World conference on sport and environment. Retrieved from http://www.olympic. org/Documents/Conferences_Forums_and_Events/Sport_and_Environment/rp-finalreport-ConferenceTorino-engl-2004.pdf (accessed May $16,2012)$

35. Olympic Review (2004). Official publication of the Olympic movement. Retrieved from http://www.olympic. org/Documents/Olympism_in_action/Development_through_Sport/ FOCUS_DEC04_ENG.pdf (accessed on May 13, 2012).

36. Parsons, T., \& Smelser, N. (2005). Economy and society: A study in the integration of economic and social theory. Routledge.

37. Pillay, U., \& Bass, O. (2008, September). Mega-events as a response to poverty reduction: The 2010 FIFA World Cup and its urban development implications. Urban Forum, 19(3), 329-346. Springer Netherlands.

38. Porter, P., \& Fletcher, D. (2008). The Economic Impact of the Olympic Games: Ex Ante Predictions and Ex Poste Reality. Journal of Sport Management, 22(4), 470-486.
39. Ritchie, B., \& Smith, B. (1991). The impact of a mega event on host region awareness - a longitudinal study. Journal of Travel Research, 30(1), 3-10.

40. Roche, M. (2000). Mega-events and modernity. London: Routledge.

41. Rose, A. K., \& Spiegel, M. M. (2010). The Olympic trade effect. Finance \& development, 47(1), 12-13.

42. Rose, A. K., \& Spiegel, M. M. (2011). The Olympic effect. The Economic Journal, 121(553), 652-677.

43. Rose, A. K., \& Spiegel, M. M. (2010). Cross-country causes and consequences of the 2008 crisis: International linkages and American exposure. Pacific Economic Review, 15(3), 340-363.

44. Smith, A. (2005). Reimaging the city the value of sport initiatives. Annals of Tourism Research, 32(1), 217-236.

45. Soroka, S. N., \& Wlezien, C. (2010). Degrees of democracy: Politics, public opinion, and policy. Cambridge University Press.

46. Tavakkoli, M. (2016). Leveraging of the Olympic Games on Mega-Sporting Events: A StrategicFramework for the Development of Sport. American Journal of Sports Science and Medicine, 4(2), 44-56.

47. Walker, M., Heere, B., Parent, M., \& Drane, D. (2010). Social responsibility and the Olympic games: The mediating role of consumer attributions. Journal of Business Ethics, 95(4), 659-680. https://doi.org/10.1007/s10551-0100445-x

48. Zawadzki, K. (2013). The impact of mega sports events on the stock markets (No. 44467). University Library of Munich, Germany. 